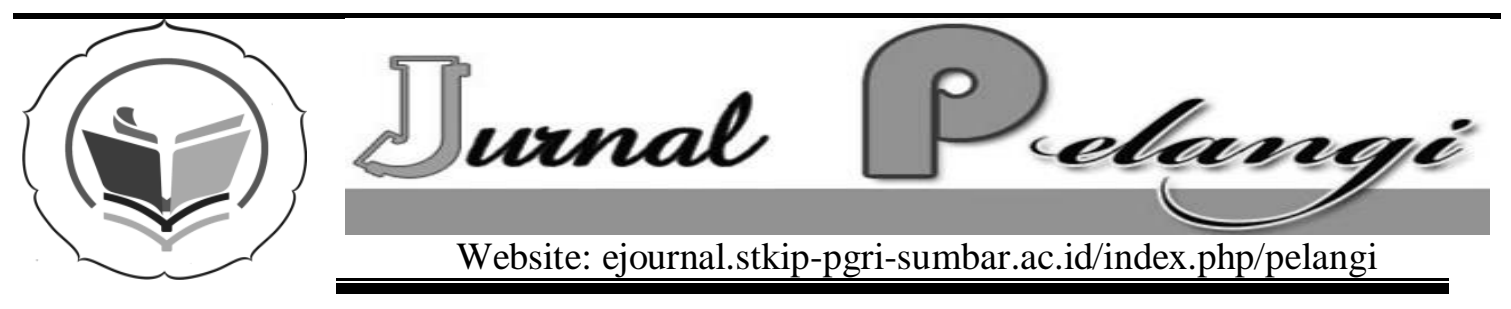

\title{
PENGARUH MODEL LEARNING CYCLE TERHADAP KEMAMPUAN PEMECAHAN MASALAH MATEMATIS SISWA KELAS VIII SMP
}

\author{
Lili Rismaini \\ UPI-YPTK Padang \\ Lilirismaini42@gmail.com
}

INFO ARTIKEL

Diterima:

1 Agustus 2016

Direview:

27 September 2016

Disetujui:

28 Desember 2016

Kata Kunci:

Learning Cycle, Pemecahan Masalah

\begin{abstract}
Abstrak
Tujuan penelitian ini adalah untuk mengetahui pengaruh model siklus belajar dan independensi belajar siswa dalam kemampuan pemecahan masalah matematika siswa khususnya pada "materi bangun ruang sisi datar". Penelitian ini dilakukan di dua kelas yaitu kelas eksperimen dan kelas kontrol. Pada kelas eksperimen pembelajaran dilakukan dengan menggunakan model siklus belajar. Pada kelas kontrol, pembelajaran dilakukan tanpa menggunakan model konvensional. Di setiap kelas siswa juga dibagi dua kelompok. Itu adalah tingkat belajar mandiri yang tinggi dan belajar mandiri yang tinggi dan tingkat belajar rendah yang independen. Data penelitian diperoleh dari hasil uji yang mempelajari independensi belajar siswa yang dilakukan sebelum dan sesudah. Analisis data dilakukan dengan menggunakan uji $t$ dan anava. Hasil penelitian menunjukkan bahwa (1) kemampuan pemecahan masalah siswa yang belajar menggunakan model siklus pembelajaran lebih tinggi daripada siswa yang belajar menggunakan model konveksi, (2) kemampuan matematika pemecahan masalah kelompok siswa yang memiliki independensi belajar tinggi. yang menggunakan model konvensional, (3) kemampuan memecahkan masalah siswa yang memiliki independensi belajar rendah yang menggunakan siklus belajar lebih tinggi dari siswa yang belajar menggunakan model konvensional, (4) tidak ada interaksi antara menggunakan model siklus belajar dengan independensi belajar tentang efek kemampuan pemecahan masalah matematika siswa.
\end{abstract}

\section{Abstract}

The research's purposes is to know the effect of learning cycle 
Learning Cycle,

Problem Solving

\section{PENDAHULUAN}

Matematika merupakan cabang ilmu pengetahuan yang memegang peranan penting dalam kehidupan manusia, yang menjadi dasar bagi ilmu-ilmu lain seperti kimia, fisika, kedokteran, ekonomi, akutansi dan ilmu lainnya. Dengan kata lain, matematika dapat dikatakan sebagai landasan bagi perkembangan ilmu pengetahuan. Matematika adalah mata pelajaran yang sangat penting bagi perkembangan kemampuan berpikir manusia. Tetapi, tidak sedikit siswa yang kurang berminat dalam mengikuti pembelajaran matematika. Mereka tidak ikut terlibat secara aktif sehingga pembelajaran yang terjadi hanya transfer pengetahuan.

Pada dasarnya tujuan pembelajaran matematika di sekolah adalah menyiapkan siswa agar dapat berkompetensi dalam memahami konsep-konsep matematika. Kompetensi atau kemahiran dalam memahami matematika diharapkan dapat dicapai melalui pembelajaran matematika.

$$
\text { Depdiknas }
$$

dalam

Permendiknas No. 22 tentang Standar Isi telah dinyatakan bahwa tujuan pembelajaran matematika di SMP/MTs, adalah agar peserta didik: (a) Memahami konsep matematika, menjelaskan keterkaitan antar konsep dan mengaplikasikan konsep atau algoritma, secara luwes, akurat, efisien, dan tepat, dalam pemecahan masalah. (b) Menggunakan penalaran pada pola dan sifat, melakukan manipulasi matematika dalam membuat generalisasi, menyusun bukti atau menjelaskan gagasan dan pernyataan matematika. (c) Memecahkan masalah yang meliputi kemampuan memahami masalah, merancang model matematika, menyelesaikan model dan menafsirkan solusi yang diperoleh. (d) Mengkomunikasikan gagasan dengan simbol, tabel, diagram, atau media lain untuk memperjelas keadaan atau 
masalah. (d) Memiliki sikap menghargai kegunaan matematika dalam kehidupan, yaitu memiliki rasa ingin tahu, perhatian, dan minat dalam mempelajari matematika, serta sikap ulet dan percaya diri dalam pemecahan masalah.

Mengingat pentingnya matematika sudah seharusnya matematika disekolah perlu diperhatikan.Telah banyak usaha yang dilakukan pemerintah untuk meningkatkan kualitas pendidikan khuusus pada mata pelajar matematika diantaranya adalah mengadakan Musyawarah Guru Mata Pelajaran (MGMP), seminar, pelatihan guru, penyempurnaan kurikulum dan lainnya.Namun usaha tersebut belum nampak hasil yang memuaskan, karena pada kenyataannya hasil belajar masih rendah.

Berdasarkan observasi dan kenyataan yang penulis temui di SMP Pertiwi 1 Padang bahwa siswa cendrung malas dalam belajar, hal ini terlihat karena banyaknya siswa yang masih berkeliaran dalam jam pelajaran sebagian siswa mengatakan bosan dalam mengikuti pelajaran sehingga hasil belajar siswa masih berlum memuaskan, ini tidak saja terjadi pada pelajaran matermatika saja tapi semua mata pelajaran. Dilihat dari hasil belajar matematika kemampuan siswa dalam mengembangkan kemampuan pemecahan masalah masih rendah. Rendahnya hasil belajar ini juga disebabkan karena siswa selalu bergantung pada orang lain dan tidak mau mencari penyelesaiannya sendiri.

Melihat berbagai permasalahan yang telah dikemukakan diatas, maka upaya yang dapat dilakukan adalah dengan menerapkan model pembelajaran yang dapat meningkatkan kompetensi dan melatih kemampuan pemecahan masalah matematik siswa, serta Meningkatkan kemampuan mereka dalam memecahkan masalah matematika. Salah satu alternatif model pembelajaran yang diperkirakan dapat memenuhi prinsipprinsip pembelajaran matematika tersebut yaitu dengan menerapkan model pembelajaran learning cycle. Model learning cycle dapat membantu siswa meningkatkan kemampuan kemampuan pemecahan masalah matematis siswa. Menurut Whandi (2008:3) "keunggulan model pembelajaran learning cycle adalah mengembangkan kemampuan siswa untuk mengajukan pertanyaan dan mencari sendiri jawabannya, membantu siswa mengembangkan pemahaman konsep serta membantu siswa berfikir mandiri". Model pembelajaran learning cycle ini memberikan kesempatan kepada siswa untuk mengembangkan pemahaman konsep, kemampuan pemecahan masalah, kemampuan berpikir kritis, serta dengan cara aktif dalam belajar baik secara mental, fisik, dan sosial.

Implementasi learning cycle dalam pembelajaran sesuai dengan pandangan konstruktivis yaitu: (1) siswa belajar secara aktif, siswa mempelajari materi secara bermakna dengan bekerja dan berpikir (2) pengetahuan dikonstruksi dari pengalaman siswa, (3) informasi baru dikaitkan dengan skema yang telah dimiliki siswa, informasi baru yang dimiliki siswa berasal dari interpretasi individu, (4) orientasi pembelajaran adalah investigasi dan penemuan yang merupakan pemecahan masalah. Dengan demikian proses pembelajaran bukan lagi sekedar transfer pengetahuan dari guru kesiswa, tetapi merupakan proses perolehan konsep yang berorientasi pada keterlibatan siswa secara aktif dan langsung.

Kemandirian belajar menjadi factor yang berperngaruh terhadap keberhasilan siswa dalam belajar. Kemandirian belajar merupakan proses pengarahan 
diri dalam mentransformasikan kemampuan mental kedalam keterampilan akademik tertentu. Sumarno (2004) mendefenisikan kemandirian belajar sebagai proses perancangan dan pemantauan yang seksama terhadap proses kognitif dan afektif dalam menyelesaikan suatu tugas akademik. Dengan adanya kemandirian belajar yang baik dari siswa, maka dalam menyelesaikan suatu masalah matematika, siswa tidak akan bergantung kepada guru ataupun orang lain. Siswa dapat memilih strategi dan melaksanakan rancangannya dalam menyelesaikan masalah serta dapat mengevaluasi hasil kerjanya.

Tulisan ini merupakan hasil penerapan pembelajaran model learning cycle sebagai usaha meningkatkan kemampuan komunikasi dan pemecahan masalah matematis siswa. Rumusan masalah yang dikembangkan dalam penelitian ini adalah sebagai berikut:

1. Apakah kemampuan pemecahan masalah matematis siswa yang mengikuti pembelajaran model learning cycle lebih baik dari kemampuan pemecahan masalah matematis siswa yang mengikuti pembelajaran konvensional?

2. Apakah kemampuan pemecahan masalah matematis siswa berkemandirian belajar tinggi yang mengikuti pembelajaran model learning cycle lebih baik dari kemampuan pemecahan masalah matematis siswa berkemandirian belajar tinggi yang mengikuti pembelajaran konvensional?

3. Apakah kemampuan pemecahan masalah matematis siswa berkemandirian belajar rendah yang mengikuti pembelajaran model learning cycle lebih baik dari kemampuan pemecahan masalah siswa berkemandirian belajar rendah yang mengikuti pembelajaran konvensional?

4. Apakah terdapat interaksi antara model pembelajaran dengan kemampuan pemecahan masalah matematis.

\section{METODE PENELITIAN}

Penelitian ini dirancang dengan menggunakan Quasy Experiment. Rancangan penelitian ynag digunakan adalah Randomized Group Only Design. Pada penelitian ini perlakuan yang diberikan pada kelas eksperimen adalah penerapan pembelajaran model learning cycle terhadap kemampuan pemecahan masalah matematis siswa, sedangkan pada kelas kontrol menggunakan pembelajaran konvensional.

Populasi pada penelitian ini adalah seluruh siswa kelas VIII SMP Pertiwi 1 Padang. Sampel pada penelitian ini dipilih secara acak, hasil pengundian diperoleh kelas VIII 1 sebagai kelas Eksperimen dan kelas VIII 2 sebagai kelas kontrol.

Instrumen dalam penelitian ini kemandirian belajar diawal penelitian dan tes akhir belajarberupa tes kemampuan pemecahan masalah matematis. Sebelum soal tes diberikan kepada siswa, terlebih dahulu divalidasi oleh beberapa ahli dan melakukan uji coba soal.

Kemandirian belajar siswa dikelompokkan menjadi siswa berkemandirian belajar tinggi dan siswa berkemandirian belajar rendah berdasarkan nilai rata-rata yaitu 2.81 . Siswa yang nilainya $\geq 2.81$ termasuk pada kemandirian belajar tinggi sedangkan siswa yang nilainya $<2.81$ termasuk pada kemandirian belajar rendah. Dari 32 siswa kelas eksperimen dan 32 siswa kelas kontrol diperoleh siswa berkemandirian belajar tinggi pada kelas eksperimen dan kontrol berturutturut 15 dan 15 orang. Siswa 
berkemampuan awal rendah pada kelas eksperimen dan kontrol diperoleh berturut-turtu 17 dan 17 orang.

Menurut Gagne dalam Ruseffendi, (2005:169) dalam pemecahan masalah ada lima langkah yang harus dilakukan yaitu: 1) menyajikan masalah dalam bentuk yang jelas; 2) menyatakn masalah dalam bentuk yang operasional (dapat dipecahkan); 3) menyusun hipotesishipotesis alernative dan prosedur kerja yang diperkirakan baik untuk dipergunakan dalam memecahkan masalah; 4) mengetes hpotesis dan melakuakn kerja untuk memperoleh hasil; 5) memeriksa kembali apakah hasil yang diperoleh benar.

Indikator pemecahan masalah yang digunakan dalam penelitian ini adalah (1) Memahami masalah atau mengajukan masalah, (2) Membuat rencana penyelesaian, (3) Melaksanakan penyelesaaian (4) Menarik kesimpulan

Data yang diperoleh selama penelitian dianalisis dengan tujuan untuk melihat apakah rata-rata skor hasil belajar kelas eksperimen lebih baik daripada kelas kontrol.

\section{HASIL DAN PEMBAHASAN}

Data tes kemampuan pemecahan masalah matematis siswa kelas ekperimen dan kelas kontrol pada Tabel 1 dapat dilihat bahwa rata-rata kemampuan pemecahan masalah siswa yang diajar dengan pembelajaran model learning cycle lebih baik dari kemampuan pemecahan masalah siswa yang diajar dengan pembelajaran konvensional.

Pada kemampuan pemecahan masalah, siswa berkemandirian belajar tinggi yang diajar dengan pembelajaran model learning cycle lebih baik dari kemampuan pemecahan masalah siswa berkemandirian belajar tinggi yang diajar dengan pembelajaran konvensional. Nilai maksimum kemampuan pemecahan masalah siswa berkemandirian belajar rendah kelas eksperimen lebih baik dibandingkan kelas kontrol. Berdasarkan data simpangan baku kelas eksperrimen lebih menyebar daripada kelas kontrol.

Rata-rata kemampuan pemecahan masalah siswa berkemandirian belajar rendah yang diajar dengan pembelajarn model learning cycle lebih baik dari kemampuan pemecahan masalah siswa berkemandirian belajar rendah yang diajar dengan pembelajaran konvensional. Nilai maksimum kemampuan pemecahan masalah siswa berkemandirian belajar rendah kelas eksperimen lebih tinggi dibandingkan kelas kontrol. Siswa berkemandirian belajar rendah pada kelas eksperimen lebih termotivasi mengikuti pembelajaran sehingga berpengaruh pada keberhasilan menjawab tes akhir.

\section{PENGUJIAN HIPOTESIS}

Persyaratan pengujian hipotesis statistik adalah dilakukannya uji prasyarat analisis. Data yang dianalisis adalah hasil tes kemampuan pemecahan masalah matematis siswa. Uji prasyarat analisis yang pertama dilakukan adalah uji normalitas dengan menggunakan uji Kolmogorov-Smirnov. Hasil pengujian dapat dilihat pada Tabel 2.

Berdasarkan Tabel 2 dapat dilihat nilai signifikansi untuk kemampuan pemecahan masalah pada kelas eksperimen dan kelas kontrol berturutturut 0,200 dan 0.154. Karena nilai signifkansi kemampuan komunikasi pada kelas eksperimen dan kelas kontrol lebih besar dari 0,05 maka dapat disimpulkan data berdistribusi normal.

Uji normalitas kemampuan pemecahan masalah siswa berkemandirian belajar tinggi pada kelas eksperimen dan kelas kontrol diperoleh nilai signifikansi berturut-turut 0,200 dan 0,131 . Artinya tes kemampuan 
pemecahan masalah siswa pemecahan masalah siswa berkemandiriberkemandirian belajar tinggi an belajar tinggi berturut-turut 0,982. berdistribusi normal.

Uji normalitas kemampuan pemecahan masalah siswa berkemandirian belajar rendah pada kelas eksperimen dan kelas kontrol diperoleh nilai signifikansi berturut-turut 0,200 dan 0,146. Artinya tes kemampuan pemecahan masalah siswa berkemandirian belajar rendah berdistribusi normal.

Uji prasyarat analisis yang selanjutnya yaitu uji homogenitas variansi dengan menggunakan analisis SPSS dengn uji Levene. Hasil analisisnya dapat dilihat pada Tabel 3.

Dari Tabel 3 diperoleh, nilai signifikansi untuk hasil tes kemampuan

Karena nilai signifikansi kemampuan pemecahan masalah siswa lebih besar dari 0,05 maka dapat disimpulkan hasil tes kemampuan pemecahan masalah siswa berkemandirian belajar tinggi kelas eksperimen dan kelas kontrol mempunyai variansi yang homogen.

Nilai signifikansi hasil tes untuk kemampuan pemecahan masalah matematis siswa berkemandirian belajar rendah berturut-turut adalah 0.413 Karena nilai signifikansi kemampuan pemecahan masalah siswa berkemandirian belajar rendah lebih besar dari 0,05 maka dapat disimpulkan data mempunyai variansi yang homogen.

Tabel 1. Data Hasil Pengukuran Tes Kemampuan Pemecahan Masalah Matematis Siswa

\begin{tabular}{ccccccc}
\hline Kelas & Kemandirian & $\mathrm{N}$ & $\bar{x}$ & $\mathrm{~S}$ & $\mathrm{X}_{\max }$ & $\mathrm{X}_{\min }$ \\
\hline Eksperimen & Tinggi & 14 & 22.14 & 4.48 & 28 & 12 \\
\cline { 2 - 7 } & Rendah & 13 & 16.92 & 5.14 & 28 & 10 \\
\cline { 2 - 7 } & Total & 27 & 19.62 & 5.00 & 28 & 10 \\
\hline \multirow{2}{*}{ Kontrol } & Tinggi & 14 & 18.00 & 4.01 & 23 & 12 \\
\cline { 2 - 7 } & Rendah & 14 & 12.85 & 3.82 & 18 & 7 \\
\cline { 2 - 7 } & Total & 28 & 15.43 & 4.65 & 23 & 7 \\
\hline
\end{tabular}

Tabel 2. Hasil Uji Normalitas Distribusi Soal Tes Akhir

\begin{tabular}{cccc}
\hline & Deskripsi & \multicolumn{2}{c}{ Pemecahan masalah matematis } \\
\hline Kelas & Kemandirian Belajar & Sig & Ket \\
\hline \multirow{2}{*}{ Eksperimen } & Tinggi & 0,200 & Normal \\
\cline { 2 - 4 } & Rendah & 0,200 & Normal \\
\cline { 2 - 4 } & Total & 0,200 & Normal \\
\hline \multirow{2}{*}{ Kontrol } & Tinggi & 0,131 & Normal \\
\cline { 2 - 4 } & Rendah & 0,146 & Normal \\
\cline { 2 - 4 } & Total & 0,154 & Normal \\
\hline
\end{tabular}

Tabel 3. Uji Homogenitas Variansi Hasil Tes

\begin{tabular}{ccc}
\hline \multirow{2}{*}{ Kemandirian Belajar } & \multicolumn{2}{c}{ Pemecahan Masalah Matematis } \\
\cline { 2 - 3 } & Sig & Ket \\
\hline Kemandirian Belajar Tinggi & 0.982 & Variansi Homogen \\
\hline Kemandirian Belajar Rendah & 0.413 & Variansi Homogen \\
\hline Kemndirian Belajar Total & 0.329 & Variansi Homogen \\
\hline
\end{tabular}


Tabel 4. Uji Hipotesis Terhadap Nilai Tes Akhir

\begin{tabular}{|c|c|c|c|}
\hline \multirow{2}{*}{ Kemandirian Belajar } & \multicolumn{3}{|c|}{ Pemecahan Masalah } \\
\cline { 2 - 4 } & Sig & $\mathrm{t}_{\text {hitung }}$ & $\mathrm{t}_{\text {tabel }}$ \\
\hline Kemandirian Belajar Tinggi & 0,004 & 2.563 & 1.703 \\
\hline Kemandirian Belajar Rendah & 0,012 & 2.164 & 1.711 \\
\hline Kemandirian Belajar Total & 0,002 & 3.045 & 1.645 \\
\hline
\end{tabular}

Tabel 5. Hasil uji anava dua arah dengan interaksi

\begin{tabular}{clllccc}
\hline Hipotesis & $\begin{array}{c}\text { Kemampuan } \\
\text { matematis } \\
\text { siswa }\end{array}$ & $\begin{array}{c}\text { Sumber } \\
\text { keberagaman }\end{array}$ & $\begin{array}{c}\text { Jumlah } \\
\text { kuadrat }\end{array}$ & Df & F & Sig \\
\hline \multirow{2}{*}{$\begin{array}{l}\text { Kemampuan } \\
\text { pemecahan } \\
\text { masalah }\end{array}$} & $\begin{array}{l}\text { Kemandirian } \\
\text { belajar }\end{array}$ & 4164,25 & 1 & $\begin{array}{c}19,98 \\
5\end{array}$ & 0,000 \\
\cline { 2 - 7 } & $\begin{array}{l}\text { Model } \\
\text { Pembelajaran }\end{array}$ & 2313 & 1 & $\begin{array}{c}11,10 \\
4\end{array}$ & 0,002 \\
\cline { 2 - 7 } & $\begin{array}{l}\text { K. belajar * } \\
\text { Model }\end{array}$ & 1,369 & 1 & 0,007 & 0,936
\end{tabular}

Berdasarkan uji prasyarat analisis, setiap kelompok data berdistribusi normal dan homogen dan selanjutnya diakukan uji hipotesis. uji statistik yang digunakan untuk hipotesis 1,2,3,5,6,7 adalah uji t. untuk hipotesis 4 dan 8 digunakan uji analisis variansi (anava dua arah). Hasil perhitungan dengan uji statistik untuk setiap hipotesis dapat dilihat pada Tabel 4.

Berdasarkan hasil perhitungan uji statistik pada Tabel 4 dan 5 diperoleh signifikansi lebih kecil dari 0,05 untuk semua hipotesis. Hal ini menunjukkan $\mathrm{H}_{0}$ ditolak dan pemecahan masalah matematis siswa yang diajar dengan pembelajaran model learning cycle lebih baik daripada kemampuan pemecahan masalah matematis siswa yang diajar dengan pembelajaran konvensional. 2) Kemampuan pemecahan masalah matematis siswa berkemandirian belajar tinggi yang diajar dengan pembelajaran model learning cycle lebih baik daripada kemampuan pemecahan masalah matematis siswa berkemandirian belajar tinggi yang menggunakan pembelajaran konvensional.

3) Kemampuan pemecahan masalah matematis siswa berkemandirian belajar rendah yang diajar dengan pembelajaran model learning cycle lebih baik daripada kemampuan pemecahan masalah matematis siswa berkemandirian belajar rendah dengan pembelajaran konvensional. 4) tidak terdapat inteeraksi antara model pembelajaran dengan kemampuan pemecahan masalah matematis.

Berdasarkan hasil analisis data yang diperoleh melalui pengujian hipotesis, terlihat bahwa hipotesis yang diajukan $\mathrm{H}_{0}$ nya di tolak. Ini berarti $\left(\mathrm{H}_{1}\right)$ diterima. Penyebab diterima atau ditolaknya $\mathrm{H}_{1}$ dapat dijelaskan sebagai berikut.

Model Learning Cycle Terhadap Kemampuan pemecahan masalah Matematis Siswa

Berdasarkan hasil pengujian hipotesis satu dan lima, dapat dilihat nilai rata-rata kemampuan pemecahan masalah matematis siswa pada kelompok yang menggunakan pembelajaran model learning cycle lebih baik dibandingkan dengan kelompok konvensional. 
Tingginya perolehan nilai pada kelompok eksperimen dikarenakan dalam proses pembelajaran dengan model learning cycle memberikan kesempatan kepada siswa untuk bekerja sama, saling bertukar pikiran dengan sesamanya dan saling membantu dalam belajar. tidak ketahui

Pada kelas konvensional konsepkonsep diperkenalkan dalam bentuk ceramah. Siswa lebih banyak menunggu penjelasan dari guru dan kurang mencari teori sendiri dari buku atau sumber yang telah mereka miliki. Hanya satu atau dua orang saja yang bertanya jika ada yang belum mengerti. Kebanyakan siswa kurang mampu menjelaskan konsep dengan bahasa mereka sendiri dan mereka cenderung membuka catatan mereka dan membacanya, siswa masih banyak yang tidak menuliskan dengan lengkap ide-ide mereka dalam menjawab soal.

Model Learning Cycle Terhadap Kemampuan pemecahan masalah Matematis Siswa Berkemandirian Belajar Tinggi

Hasil pengujian hipotesis kedua dan keenam menunjukan bahwa secara umum kemampuan pemecahan masalah kelompok siswa yang memiliki kemandirian belajar tinggi memperoleh hasil yang lebih baik dengan menggunakan pembelajaran model learning cycle dari pada siswa yang menggunakan pembelajaran konvensional. Melalui model learning cycle ini, siswa yang memiliki kemandirian belajar tinggi dapat mempertinggi keaktifannya dalam belajar. Kondisi seperti ini menjadi lebih baik karena didukung pembelajaran dengan kelompok dan difasilitasi oleh LKS. Menurut Rousseau sebagaimana dikutip Sumakdinata (2003:168) meenyatakan bahwa, "anak memiliki potensi-potensi yang masih terpendam, melalui belajar anak harus diberi kesempatan mengembangkan atau mengaktualkan potensi-potensi tersebut". Siswa yang memiliki kemandirian belajar tinggi dapat menjelaskan serta mengulang kembali konsep-konsep yang sedang dipelajari pada saat membantu teman-teman dalam kelompoknya. Kebanyakan siswa yang memiliki kemandirian belajar tinggi dapat dengan mudah mengerjakan latihan dengan baik dan benar.

Pada model konvensional siswa yang memiliki motivasi belajar yang tinggi kesempatannya untuk menemukan konsep sendiri atau berkolaborasi dengan teman sangat terbatas karena proses pembelajaran didominasi oleh guru. Sementara siswa hanya menerima pelajaran dengan pasif, seperti yang diungkapkan Tengku Zahara Djaafar (2001) yang mengatakan pembelajaran konvensional ditafsirkan memasukkan isi atau bahan dari buku kepada siswa hingga mereka dapat mengeluarkan kembali informasi waktu tes.

Model Learning Cycle Terhadap Kemampuan pemecahan masalah Matematis Siswa Berkemandirian Belajar Rendah

Hasil pengujian hipotesis ketiga dan ketujuh menunjukan bahwa secara umum kemampuan pemecahan masalah kelompok siswa yang memiliki kemandirian belajar rendah yang menggunakan pembelajaran model learning cycle memperoleh hasil lebih baik dari pada siswa yang menggunakan pembelajaran konvensional.

Tidak terdapat Interaksi Antara Model Learning Cycle Dan Kemampuan Awal Terhadap Kemampuan Pemahaman Konsep Matematika Siswa

Berdasarkan hasil analisis pada pengujian hipotesis keempat dan kedelapan, dapat disimpulkan bahwa 
tidak terdapat interaksi antara model learning cycle dengan kemandirian belajar terhadap kemampuan pemecahan masalah. Dengan tidak adanya interaksi ini menunjukkan bahwa model learning cycle secara signifikan telah mampu meningkatkan hasil belajar terutama kemampuan pemecahan masalah matematis siswa.

Tidak terdapat interaksi antara pembelajaran model learning cycle dengan kemandirian belajar terhadap kemampuan pemecahan masalah matematis siswa antara lain disebabkan oleh: (1) siswa belum pernah menggunakan pembelajaran model learning cycle, (2) keterbatasan waktu bagi peneliti untuk melakukan sosialisasi kepada siswa tentang model pembelajaran ini, (3) ada sebagian siswa yang kurang peduli dan kurang berkolaborasi atau bekerja sama terhadap temannya.Hal ini mengisyaratkan bahwa model learning cycle dapat digunakan dalam berbagai situasi dalam pembelajaran tanpa mempertimbangkan terlebih dahulu kemandirian belajar.

\section{PENUTUP}

Berdasarkan hasil penelitian di atas dapat dismpulkan sebagai berikut.

1. Kemampuan pemecahan masalah siswa yang menggunakan pembelajaran model learning cyclebaik dari pada siswa yang menggunakan pembelajaran konvensional.

2. Kemampuan pemecahan masalah siswa yang berkemandirian belajar tinggi yang mengikuti pembelajaran dengan model learning cycle lebih baik dari pada siswa yang menggunakan pembelajaran konvensional.

3. Kemampuan pemecahan masalah siswa yang berkemandirian belajar rendah yang mengikuti pembelajaran dengan model learning cycle lebih baik dari pada siswa yang menggunakan pembelajaran konvensional.

Tidak terdapat interaksi antara model learning cycle dengan kemandirian belajar siswa terhadap kemampuan pemecahan masalah matematis siswa.

\section{UCAPAN TERIMA KASIH}

Terbitnya tulisan ini tidak terlepas dari bantuan berbagai pihak, untuk itu penulis ucapkan terima kasih kepada UP3M STKIP PGRI Sumatera Barat sebagai penyandang dana dan pengelola jurnal Pelangi yang telah memberikan saran dan revisi dalam penulisan artikel ini.

\section{DAFTAR PUSTAKA}

Departemen Pendidikan Nasional. 2006. Peraturan Mentri Pendidikan Nasional No. 22, 23, 24. Jakarta: Depdiknas

Erman Suherman, dkk. 2003. Strategi Pembelajaran Matematika Kontenporer. Bandung: JICA Universitas Pendidikan Indonesia

Fajaroh, F \& I Wayan Dasna. 2008. Pembelajaran Dengan Model Siklus Belajar(learning cycle). Sahaka.multiplay.com/journal. (diakses 15 juli 2011

Lie, anita. 2002. Cooperative Learning : Memppraktikkan Cooperative Learning di Ruang-ruang Kelas. Jakarta : Grasindo

Ruseffendi.1991.Dasar-dasarMatematika Modern. Bandung: Tarsito

Slameto. 2003. Belajar dan Faktor-faktor yang Mempengaruhinya. Jakarta: PT Rineka Cipta 
Sumarmo. (2004). Kemandirian Belajar: Apa, Mengapa dan Bagaimana Dikembangkan pada Peserta Didik. Makalah disajikan pada Seminar Pendidikan Matematika di Jurusan Pendidikan Matematika FMIPA Universitas Negeri Yogyakarta, tanggal 8 Juli 2004. Tidak diterbitkan

Tengku Zahara D. 2001. Kontribusi Strategi Pembelajaran Terhadap Hasil Belajar. Padang: FIP UNP
Whandi. 2008. Pembelajaran Konstruktifistik. http://whandi.net. $\mathrm{Html}$

Yerizon. (2011). Peningkatan Kemampuan Pembuktian dan Kemandirian Belajar Matematika Mahasiswa melalui Pendekatan MPos. Disertasi. Bandung: pasca sarjana universitas pendidikan indonesia 